\title{
Glucose, Acetate, and Lactate Metabolism in Perirenal Adipose Tissue of Fetal and Newborn Calves
}

\author{
MAHENDRA S. WIJAYASINGHE \\ Department of Animal Science, University of California, Davis, California 95616
}

\begin{abstract}
Rates of utilization of glucose, acetate, and lactate and activities of selected enzymes were determined in vitro to characterize the nature of lipogenesis and metabolite utilization in perirenal adipose tissue from 6- to 7month old fetal and 3- to 4-h-old unsuckled newborn calves. Contribution of the pentose phosphate cycle to glucose metabolism was estimated using specifically labeled glucose. Rates of fatty acid synthesis from all three substrates and oxidation of glucose were much greater in fetal than in newborn adipose tissue. In fetal adipose tissue, acetate and lactate were major sources of carbon for fatty acid synthesis; glucose functioned mainly by metabolism via the pentose phosphate cycle to provide reducing equivalents for fatty acid synthesis and by incorporation into glyceride glycerol for fatty acid esterification. Pentose phosphate cycle contributed 58 and $12 \%$ to glucose metabolism in adipose tissue of fetal and newborn calves, respectively. Adipose tissue metabolism of newborn calves was characterized by greatly depressed rates of fatty acid synthesis despite high enzyme activities and elevated rates of glyceride glycerol synthesis. (Pediatr Res 20: 542-544, 1986)
\end{abstract}

Most studies of fetal metabolism have been carried out in sheep with substrate utilization usually being determined on the basis of rates of oxygen consumption and uptake of different substrates. Various acute and chronic preparations and techniques such as the isolated fetus, the exteriorized fetus, and the chronically catheterized fetal lamb preparation, have enabled researchers to gain an insight into fetal metabolism and physiology (1). Although these studies have provided valuable data, detailed information on the metabolism of substrates by individual fetal tissues and organs is still lacking, particularly in the bovine.

Substrates available to the fetus are used for three purposes: synthesis of new tissue, oxidative metabolism, and building of energy reserves. The primary energy reserves that accumulate within the fetus in the latter part of gestation are glycogen and lipids. Together, these represent the major stores that provide for energy needs of the newborn ruminant in the immediate postnatal period (2). In the sheep fetus accumulation of lipids appears to occur primarily via de novo synthesis from various substrates (2), and the adipose tissue appears to be an important site of fatty acid synthesis (3). With the abrupt introduction of the fetus to an extrauterine existence, immediate changes may be expected to occur in lipid metabolism. Answers to many questions con-

Received September 9, 1985; accepted February 3, 1986.

Address for correspondence and reprints Dr. M. S. Wijayasinghe, Department of Animal Science, 310, Agriculture-Forestry Building, University of Alberta, Edmonton, Alberta, Canada T6G 2P5.

Supported by a University of California Regents' Fellowship. cerning such changes in lipid metabolism have yet to be obtained The present investigation involved studies of adipose tissue from fetal and unsuckled newborn calves. Rates of utilization of glucose, acetate, and lactate, as substrates for oxidation and for synthesis of fatty acids and glyceride glycerol, were determined in vitro to characterize the nature of lipogenesis and patterns of metabolite utilization. Specifically labeled glucose was employed to evaluate the contribution of the pentose phosphate cycle to glucose metabolism and to the reducing equivalents needed for fatty acid synthesis. In addition, activities of selected enzymes related to lipogenesis in adipose tissue were also assayed.

\section{MATERIALS AND METHODS}

Perirenal adipose tissue samples were obtained from five fetal calves (180-210 days gestation or 64-75\% of full term) and eight newborn unsuckled calves (3-4 h after birth). Newborn calves were sacrificed by exsanguination prior to tissue removal. Adipose tissue samples were placed in warm saline $\left(37^{\circ} \mathrm{C}\right)$ for transport to the laboratory, cleaned of connective tissue and blood vessels, and cut into small (30-50 mg) pieces. Adipose tissue pieces weighing $50-100 \mathrm{mg}$ were placed in siliconized 25 ml Erlenmeyer flasks containing $2 \mathrm{ml}$ of incubation medium (Table 1). Concentrations of glucose, acetate, lactate/pyruvate, and insulin in the incubation medium were determined in the preliminary experiment to achieve maximum rates of substrate utilization. The flasks were gassed with a mixture of $95 \% \mathrm{O}_{2}$ and $5 \% \mathrm{CO}_{2}$, capped with self-sealing rubber serum caps fitted wth plastic center wells, and incubated for $2 \mathrm{~h}$ at $37^{\circ} \mathrm{C}$ in a shaking (100 cycles $/ \mathrm{min}$ ) water bath. At the end of incubation, $0.5 \mathrm{ml}$ of $1 \mathrm{~N} \mathrm{H}_{2} \mathrm{SO}_{4}$ was injected into the flasks and $0.2 \mathrm{ml}$ of hyamine hydroxide (Sigma, St. Louis, MO) was injected into the center wells. Flasks were shaken for another $1 \mathrm{~h}$ to allow $\mathrm{CO}_{2}$ absorption by hyamine. Incorporation of labeled substrates into triacyl glycerol and fatty acids were determined by the method of Dole (5), as modified by Rodbell (6). The air dried triacyl glycerol and fatty acid extracts and $\mathrm{CO}_{2}$ absorbed in hyamine were dissolved in $0.4 \%$ Omniflour (New England Nuclear Co., Boston, MA) toluene counting fluid. Radioactivity was determined in a Packard liquid scintillation spectrometer. Substrate conversions were calculated from initial substrate specific radioactivity and radioactivities of the products.

Samples of adipose tissue from each animal were immediately homogenized in $0.14 \mathrm{M} \mathrm{KCl}\left(37^{\circ} \mathrm{C}\right)$ with a Potter-Elvehjem homogenizer. Tissue homogenates were centrifuged in a Sorvall refrigerated centrifuge for $20 \mathrm{~min}$ at $35,000 \times \mathrm{g}$. The aqueous fractions were assayed for enzyme activities. Citrate cleavage enzyme (EC 4.1.3.7), glucose 6-phosphate dehydrogenase (EC 1.1.1.49), 6-phosphogluconate dehydrogenase (EC 1.1.1.44), NADP-isocitrate dehydrogenase (EC 1.1.1.42), and NAD-malate dehydrogenase (EC 1.1.1.37) were assayed as described by Baldwin and Milligan (7). NADP-malate dehydrogenase (malic en- 
zyme, EC 1.1.1.40), and lactate dehydrogenase (EC 1.1.1.27) were assayed according to Ochoa (8) and Bergmeyer et al. (9), respectively. Enzyme assays were conducted in the linear range of activity at $25^{\circ} \mathrm{C}$ using a Gilford spectrophotometer fitted with a multiple absorbance recording system. Protein was determined in the aqueous fractions by the method of Lowry et al. (10), using bovine serum albumin as the standard.

Bovine insulin and other biochemicals were purchased from Sigma. Sources of labeled substrates were: $\mathrm{U}-{ }^{14} \mathrm{C}$ glucose and 2${ }^{14} \mathrm{C}$ lactate (Amersham Searle, Arlington Heights, IL); $1-{ }^{14} \mathrm{C}$ glucose (ICN Pharmaceutical Inc, Irvine, CA), and $6-{ }^{14} \mathrm{C}$ glucose (Research Products International, Elkgrove Village, IL).

\section{RESULTS}

Metabolic rates for adipose tissue (Tables 2 and 3) are expressed per mg soluble protein for reasons given in the discussion. Soluble protein content (Table 2) in adipose tissue from fetal calves was significantly greater $(p<0.001)$ than that from newborn calves. All enzyme activities appeared very much depressed in newborn calves when expressed on a tissue wet weight basis (results not shown), but activities expressed on a soluble protein basis (Table 2) exceeded or equalled those of fetal adipose tissue except for citrate cleavage enzyme. Even the reduced activity of citrate cleavage enzyme was at least 80 - and 40 -fold higher than the observed rates of fatty acid synthesis from glucose

Table 1. Composition of incubation medium

\begin{tabular}{lc}
\hline Krebs Ringer bicarbonate buffer, & $90 \mathrm{ml}$ \\
pH 7.4* & \\
Bovine serum albumin $\dagger$ & $2 \mathrm{~g}$ \\
Amino acid mixture $\ddagger$ & $10 \mathrm{ml}$ \\
Glucose $§$ & $20 \mathrm{mM}$ \\
Acetate\| & $5 \mathrm{mM}$ \\
L-Lactate/pyruvate $(9: 1) \uparrow$ & $5 \mathrm{mM}$ \\
Insulin & $100 \mathrm{mU} / \mathrm{ml}$ \\
& \\
Final volume, made up with buffer & $100 \mathrm{ml}$ \\
\hline
\end{tabular}

* Krebs buffer containing $1 / 2$ recommended [Ca], gassed for $1 \mathrm{~h}$ with $95 \% \mathrm{O}_{2}+5 \% \mathrm{CO}_{2}$ mixture.

$\dagger$ Defatted (4) and dialysed for $48 \mathrm{~h}$ against double deionized water.

$\ddagger 100 \mathrm{ml}$ amino acid mixture contained $300 \mathrm{mg}$ casein hydrolysate, $10 \mathrm{mg}$ methionine, and $10 \mathrm{mg}$ tryptophan.

$\S$ Combined with $\mathrm{U}-{ }^{14} \mathrm{C}, 1-{ }^{14} \mathrm{C}$, or $6-{ }^{14} \mathrm{C}$ glucose.

II Combined with $1{ }^{14} \mathrm{C}$ acetate.

II Combined with $2{ }^{14} \mathrm{C}$ lactate.

Table 2. Enzyme activities in the perirenal adipose tissue of fetal and newborn calves

\begin{tabular}{|c|c|c|}
\hline Enzyme $e^{*} \dagger$ & Fetal & Newborn \\
\hline CCE & $0.098 \pm 0.025$ & $0.019 \pm 0.011 \ddagger$ \\
\hline $\mathrm{ME}$ & $0.034 \pm 0.006$ & $0.172 \pm 0.043 \S$ \\
\hline $\mathrm{MDH}$ & $0.632 \pm 0.097$ & $5.580 \pm 0.933 \ddagger$ \\
\hline G6-PD & $0.185 \pm 0.033$ & $0.199 \pm 0.035^{\circ}$ \\
\hline 6-PGD & $0.087 \pm 0.010$ & $0.541 \pm 0.121 \S$ \\
\hline $\mathrm{ICD}$ & $0.593 \pm 0.084$ & $4.060 \pm 0.841 \ddagger$ \\
\hline $\mathrm{LDH}$ & $3.590 \pm 0.403$ & $11.550 \pm 2.190 \S$ \\
\hline Soluble protein $(\mathrm{mg} / \mathrm{g})$ & $16.91 \pm 1.79$ & $2.49 \pm 0.87 \|$ \\
\hline
\end{tabular}

* Units in $\mu \mathrm{mol}$ substrate converted per min per mg tissue soluble protein; mean \pm SEM; $n=5$ fetal and 8 newborn calves.

$\dagger \mathrm{CCE}$, citrate cleavage enzyme; $\mathrm{ME}$, malic enzyme; $\mathrm{MDH}$, malate dehydrogenase; G6-PD, glucose-6-phosphate dehydrogenase; 6-PGD, 6phosphogluconate dehydrogenase; ICD, isocitrate dehydrogenase; $\mathrm{LDH}$, lactate dehydrogenase.

$\ddagger p<0.01, \S p<0.05, \| p<0.001$ significant differences, (Student's $t$ test). and lactate and, therefore, does not appear to limit fatty acid synthesis in the newborn.

The sum of the rates of oxidation of glucose, acetate, and lactate in adipose tissue from newborn calves was nearly 6-fold higher than that from fetal calves (Table 3 ). However, the pattern of substrate oxidation differed in the two groups; the rate of glucose oxidation in adipose tissue from fetal calves exceeded ( $p$ $<0.01$ ) that of newborn calves, while the opposite was true for rates of oxidation of acetate and lactate $(p<0.01)$.

Rates of conversion of glucose, acetate, and lactate to fatty acids were depressed by $11-, 2.4-$, and 20 -fold, respectively, in adipose tissue of newborn calves when compared with those of fetal calves. On the basis of acetyl-CoA units incorporated into fatty acids in fetal adipose tissue, acetate exceeded glucose and lactate by $5-$ and 1.5 -fold, respectively. The rate of incorporation of glucose carbons into glyceride glycerol in newborn adipose tissue was significantly greater $(p<0.05)$ than that of fetal adipose tissue. The ratio of glucose- $1-{ }^{14} \mathrm{C} /$ glucose $-6-{ }^{14} \mathrm{C}$ conversion to $\mathrm{CO}_{2}$, an index of the activity of pentose phosphate cycle (11), was 4.4 and 1.8 for adipose tissue from fetal and newborn calves, respectively. The contribution of the pentose phosphate cycle to glucose metabolism was calculated using specific ${ }^{14} \mathrm{CO}_{2}$ yields and fatty acid ratios from glucose $1-{ }^{14} \mathrm{C}$ and $6-{ }^{14} \mathrm{C}$, as described by Katz et al. (12). The reference value used to calculate specific yields was computed by summing glucose incorporation into $\mathrm{CO}_{2}$ and triacyl glycerol. Calculated percentage contribution of the pentose phosphate cycle to glucose metabolism in adipose tissue was signficantly greater $(p<0.001)$ in fetal $(58 \pm 2)$ than in newborn calves $(12 \pm 5)$.

\section{DISCUSSION}

Difficulties encountered in establishing a satisfactory and meaningful reference base for expression of metabolic and enzyme data from adipose tissue have been noted by several workers $(3,6,13-15)$. Expression of results on a cellular or a protein basis appear to be preferred methods for evaluating adipose tissue metabolism $(3,13)$. However, in neonatal animals cellular hypertrophy and marked variations in adipocyte sizes in animals of the same chronological age can complicate the evaluation of age-related changes in adipose tissue metabolism (3, 15). Fat cells from fetal calves can be expected to be smaller than those of newborn calves (3). Thus, changes in metabolic activity per unit weight of tissue may merely reflect changes in adipocyte number rather than true age-related differences. In the present study, the observation of a 6-fold reduction in soluble protein content of adipose tissue between the fetal and newborn state (Table 2) provides indirect evidence for the occurrence of marked cellular hypertrophy and lipid accumulation in perirenal adipose tissue during the last trimester of gestation. In order to compensate for these changes in cellularity, and with the above noted limitations in mind, all results of the present study were expressed on the basis of tissue soluble protein content.

Acetate, lactate, and glucose were preferred in that order as substrates for fatty acid synthesis in both fetal and newborn calf adipose tissue (Table 3). A similar order of preference also exists in the adipose tissue of adult ruminants (3). That acetate traverses the placenta and is used in oxidative and synthetic reactions by the fetal lamb has been established (16). The ratios of acetate carbons:glucose carbons incorporated into fatty acids in adipose tissue of adult ruminants vary between $10-100$ (3). The same ratio, when computed for fetal calves in the present study, was 5 , indicating a greater capacity of fetal adipose tissue to extract and utilize glucose for fatty acid synthesis. This capability may also be reflected in the relatively high activities of both citrate cleavage and malic enzymes in adipose tissue of fetal and newborn calves in comparison to activities reported (3) for adult ruminants. This study provides the first in vitro evidence for the role of lactate as an important precursor for fatty acid synthesis in adipose tissue of the bovine fetus (Table 3). Activities of lactate 
Table 3. Patterns of glucose, acetate, and lactate metabolism in perirenal adipose tissue of fetal and newborn calves*

\begin{tabular}{|c|c|c|c|c|c|c|}
\hline \multirow{2}{*}{$\frac{\text { Substrate and label }}{\text { Products }}$} & Fetal & Newborn & Fetal & Newborn & Fetal & Newborn \\
\hline & \multicolumn{2}{|c|}{$\mathrm{CO}_{2}$} & \multicolumn{2}{|c|}{ Fatty acids } & \multicolumn{2}{|c|}{ Glyceride glycerol } \\
\hline Glucose & 575.5 & $288.5 \dagger$ & 154.3 & $13.6 \ddagger$ & 73.7 & $176.3 \S$ \\
\hline $\mathrm{U}-{ }^{14} \mathrm{C}$ & \pm 73.3 & \pm 23.5 & \pm 36.5 & \pm 3.1 & \pm 5.8 & $\pm 32.0^{\circ}$ \\
\hline Glucose & 740.0 & $358.6 \ddagger$ & 91.3 & $21.5 \ddagger$ & 15.9 & $117.8 \S$ \\
\hline $1-{ }^{14} \mathrm{C}$ & \pm 92.3 & \pm 26.4 & \pm 17.8 & \pm 6.9 & \pm 4.0 & \pm 32.4 \\
\hline Glucose & 167.2 & 203.6 & 237.9 & $20.9 \dagger$ & 154.1 & 273.7 \\
\hline${ }^{6-14} \mathrm{C}$ & \pm 21.4 & \pm 22.7 & \pm 68.3 & \pm 3.7 & \pm 32.2 & \pm 51.5 \\
\hline Acetate & 249.4 & $5194.8 \dagger$ & 1554.1 & $642.2 \dagger$ & 72.2 & 54.4 \\
\hline $1-{ }^{14} \mathrm{C}$ & \pm 38.8 & \pm 968.0 & \pm 152.1 & \pm 191.8 & \pm 50.8 & \pm 26.7 \\
\hline Lactate & 443.6 & $1557.6 \dagger$ & 1036.0 & $52.0 \ddagger$ & 48.2 & $17.1 \dagger$ \\
\hline $2-{ }^{14} \mathrm{C}$ & \pm 69.5 & \pm 260.1 & \pm 191.7 & \pm 14.1 & \pm 11.3 & \pm 4.0 \\
\hline
\end{tabular}

*Values given in nanomoles substrate converted to products per $2 \mathrm{~h}$ per mg tissue soluble protein; mean \pm SEM; $n=5$ fetal and 8 newborn calves.

$\dagger p<0.01, \ddagger p<0.001, \S p<0.05$ significant differences, (Student’s $t$ test).

dehydrogenase in both fetal and newborn calf adipose tissue appear nonlimiting and are far in excess of the sum of the rates of lactate oxidation and incorporation into triacyl glycerol (Tables 2 and 3 ). The importance of lactate as a major exogenous nutrient for the developing fetal lamb has been recognized (17, 18).

The ratios of glucose $1-{ }^{14} \mathrm{C} /$ glucose $6-{ }^{14} \mathrm{C}$ conversion to $\mathrm{CO}_{2}$ and the calculated (see "Results") contribution of the pentose phosphate cycle to glucose metabolism indicate that metabolism of glucose via pentose phosphate cycle is increased in adipose tissue of fetal and depressed in adipose tissue of newborn calves. However, activities of glucose-6-phosphate dehydrogenase were similar in both groups of calves, while those of 6-phosphogluconate dehydrogenase were increased in the newborn (Table 2). The equations used in this study to calculate the contribution of pentose phosphate cycle to glucose metabolism were developed by Katz et al. (12) for white adipose tissue of the rat. Baldwin and Smith (11) have noted that the assumptions involved in these equations may not be applicable to adipose tissue of the adult ruminant. Whether these assumptions are applicable to adipose tissue of the bovine neonate is not known. Thus, calculations done in the present study may only provide a general idea of the magnitude of the pentose phosphate cycle. Assuming that the calculated values of 58 and $12 \%$ are reasonable estimates, further calculations based on the methods of Rognstad and Katz (19) show that pentose phosphate cycle contributes $100 \%$ of the NADPH requirement for fatty acid synthesis from acetate in fetal calves and $42 \%$ of the same in newborn calves. Pentose phosphate cycle is thought to make a major contribution to NADPH production in adipose tissue of adult ruminants (3). Two other potential sources of reducing equivalents in the adipose tissue are NADP-malate dehydrogenase and the NADPlinked isocitrate dehydrogenase enzyme. It appears, from the activities of these two enzymes (Table 2), that they may also play a role in NADPH production in adipose tissue of the bovine neonate.

The most striking difference observed between fetal and newborn calves (Tables 2 and 3) is the markedly depressed rate of fatty acid synthesis in adipose tissue of the newborn despite high enzyme activities and increased rates of glyceride glycerol synthesis. Calculations show that de novo fatty acid synthesis in newborn adipose tissue could account for only $7 \%$ of the total fatty acids esterified and indicate apparently high rates of lipolysis in this tissue. The potential ability of perirenal adipose tissue to mobilize lipids to meet energy needs of the neonatal ruminant has been recognized previously (2).
This study provides additional insight into the metabolism of glucose, acetate, and lactate in perirenal adipose tissue of the bovine neonate. It appears that in fetal adipose tissue both acetate and lactate are major sources of carbon for fatty acid synthesis and that glucose functions mainly to provide reducing equivalents for fatty acid synthesis and glyceride glycerol for fatty acid esterification. In newborn adipose tissue fatty acid synthesis is depressed and lipolysis appears to be elevated. The latter observation may relate to mobilization of free fatty acids to meet energy demands in the immediate postnatal period.

\section{REFERENCES}

1. Battaglia FC, Meschia G 1978 Principal substrates of fetal metabolism. Physiol Rev 58:499-527

2. Noble RC 1980 Lipid metabolism in the neonatal ruminant. Prog Lipid Res 18:179-216

3. Vernon RG 1980 Lipid metabolism in the adipose tissue of ruminant animals. Prog Lipid Res 19:23-106

4. Chen RF 1967 Removal of fatty acids from serum albumin by charcoal treatment. J Biol Chem 242:173-181

5. Dole VP 1956 A relationship between non-esterified fatty acids in plasma and the metabolism of glucose. J Clin Invest 35:150-154

6. Rodbell M 1964 Metabolism of isolated fat cells. I. Effects of hormones on glucose metabolism in isolated fat cells. J Biol Chem 239:375-384

7. Baldwin RL, Milligan LP 1966 Enzymatic changes associated with the initiation and maintenance of lactation in the rat. J Biol Chem 241:2058-2066

8. Ochoa S 1955 Malic Enzyme. In: Colowick SP, Kaplan NO (eds) Methods in Enzymology. Academic Press, New York, pp 739-740

9. Bergmeyer HU, Bernt E, Hess B 1965 Lactic Dehydrogenase. In: Bergmeyer HU (ed) Methods of Enzymatic Analysis. Academic Press, New York, pp $736-741$

10. Lowry OH, Rosebrough NJ, Farr AL, Randall RJ 1951 Protein measurement with the Folin phenol reagent. J Biol Chem 193:265-275

11. Baldwin RL, Smith NE 1971 Intermediary aspects and tissue interactions of ruminant fat metabolism. J Dairy Sci 54:583-595

12. Katz J, Landau BL, Bartsch GE 1966 The pentose cycle, triose phosphate isomerization and lipogenesis in rat adipose tissue. J Biol Chem 241:727740

13. Hood RL, Allen CE 1973 Comparative methods for the expression of enzyme data in porcine adipose tissue. Comp Biochem Physiol 44B:677-686

14. Salans LB, Knittle JL, Hirsch J 1968 The role of adipose cell size and adipose tissue insulin sensitivity in the carbohydrate intolerance of human obesity. $J$ Clin Invest 47:153-165

15. Vernon RG 1976 Effect of dietary safflower oil upon lipogenesis in neonatal lamb. Lipids 10:284-289

16. Char VC, Creasy RK 1976 Acetate as a metabolic substrate in the fetal lamb. Am J Physiol 230:357-361

17. Char VC, Creasy RK 1976 Lactate and pyruvate as fetal metabolic substrates. Pediatr Res 10:231-234

18. Sparks JW, Hay WW, Bonds D, Meschia G, Battaglia FC 1982 Simultaneous measurement of lactate turnover rate and umbilical lactate uptake in the fetal lamb. J Clin Invest 70:179-192

19. Rognstad R, Katz J 1966 The balance of pyridine nucelotides and ATP in adipose tissue. Proc Natl Acad Sci USA 55:1 148-1157 